\title{
Elogio do anacronismo: afetos, memórias, experiências, em Asas do Desejo, de Wim Wenders
}

\section{In Praise of Anachronism: Affections, Memories, Experience, in Wings by Desire, of Wim Wenders}

\author{
Alexandre Fernandez Vaz*
}

\begin{abstract}
RESUMO
Tomando como objeto o filme "Asas do desejo", de Wim Wenders, o presente trabalho analisa um conjunto de questões estéticas e políticas do nosso tempo, considerando, por paradoxal que seja, o caráter anacrônico daquela obra. Procura um diagnóstico do tempo em dois momentos, o da Guerra Fria e o das condições subjetivas em uma cidade, Berlim, que sintetiza o espírito pós-utópico. Para tanto, analisa a figura dos anjos, recolocando a relação entre desejo e materialidade, de onde emerge a questão da experiência. Os anjos vivem em condição etérea, lembram-se de tudo, apesar da ausência de corpo, o que os deixa em eterno presente, apartados da história. Metodologicamente, o trabalho encontra um anteparo para o filme na obra de Walter Benjamin, cujos textos sobre Berlim articulam memória social e literatura. Se os anjos são o fio que conduz a narrativa, outros personagens incorporam temas também analisados: o velho narrador, os sentidos abertos das crianças, o desejo pela trapezista. Observando o duplo sentido de errar e a condição de desejante de um dos anjos, o texto conclui com a ideia segundo a qual é o desejo que inscreve o ser humano na história.
\end{abstract}

Palavras-chave: Arte e Educação. Educação dos sentidos. Wenders. Wim. Benjamin. Walter. Memória e História.

* Universidade Federal de Santa Catarina. Florianópolis, Santa Catarina, Brasil. E-mail: alexfvaz@uol.com.br. https://orcid.org/0000-0003-4194-3876. 


\begin{abstract}
Taking Wim Wenders' film "Wings of Desire" as an object, this paper analyzes some aesthetic and political issues of our time, considering, paradoxically, the anachronistic character of that artwork. It looks for a diagnosis of present time in two moments, that of the Cold War and that of subjective conditions in the city of Berlin, which synthesizes the post-utopian spirit. To do so, the paper analyzes the figure of the angels, reinstalling the relation between desire and materiality, from which emerges the issue of experience. The angels live in ethereal condition; they remember everything, despite the absence of body, which leaves them in eternal present, away from history. Methodologically, the paper dialogues with Walter Benjamin, whose texts on Berlin articulate social memory and literature. While the angels are the thread that leads the narrative, other characters are also essential: the old storyteller, the children's open senses, and the desire for the trapeze artist. Observing the double sense of error and the desiring condition of one of the angels, the paper concludes with the idea that it is the desire that inscribes the human being in history.
\end{abstract}

Keywords: Art and Education. Education of the Senses. Wenders. Wim. Benjamin. Walter. Memory and History.

\title{
Uma cidade em dois atos
}

Em 1950, Theodor W. Adorno se encarregou da publicação de Infância berlinense: 1900, livro de Walter Benjamin nunca publicado durante sua breve vida, encerrada com o suicídio em Portbou, lado catalão de uma fronteira franco-espanhola, aos quarenta e oito anos. A história é conhecida. Benjamin fugia da perseguição nacional-socialista que o havia encurralado também na França, último país por onde perambulara e no qual se dedicava a escrever sua inacabada obra Passagens. De lá tentava fugir a caminho dos Estados Unidos da América para juntar-se ao Instituto de Investigação Social, antes sediado em Frankfurt e, naquele momento, associado à Universidade de Columbia, em Nova York.

A publicação do livro de Benjamin se coloca no contexto da divulgação mais extensa de sua obra, então conhecida apenas em círculos intelectuais mais restritos, e da volta dos exilados centro-europeus, judeus de esquerda em sua maioria, à Europa, uma vez finda a Segunda Guerra Mundial. A versão levada a livro pela primeira vez é a que ficou conhecida por Felizitas, aquela que Benjamin enviara a Gretel, esposa de Teddy e sua grande amiga de anos de convívio em Berlim e de longa correspondência posterior. Felizitas era como 
Benjamin se referia à amiga, destino, junto com outros e outras, de grande parte de sua produção intelectual, distribuída entre os de sua confiança com o intuito de receber a leitura crítica, mas também de preservar materiais que talvez não sobrevivessem a tantas mudanças de domicílio, e à crescente condição precária de existência.

No posfácio ao livro, Adorno (1997a) afirma que nunca alguém se reconhecera tão bem em uma cidade como Benjamin em Berlim. Tal valoração se destina a uma obra que é um conjunto de breves textos escritos e reescritos, montados e remontados, suprimidos e incluídos, que retoma partes de outro trabalho, Crônica berlinense, e que haviam sido publicados, desde o final de 1924, em suplementos culturais e revistas literárias. Memórias fragmentárias e dissonantes em relação à cronologia, tanto porque interessava a montagem como método - fosse a do cinema, dialética, fosse a surrealista, ambas do choque, como se lê em notas e ensaios referentes a Passagens - quanto porque o tempo qualitativo se expressa em espessura e intensidade, não em ordem de fatos justapostos e supostamente coerentes. Benjamin trafegava na contramão do historicismo como seria teorizado no último de seus escritos conhecidos, as teses de Sobre o conceito de história.

Na versão publicada sob responsabilidade de Adorno - haveria outras, a última encontrada por Giorgio Agamben em 1981, dedicada ao filho Stefan - o livro começa com um aforisma de importante orientação metodológica. Ele diz que orientar-se em uma cidade é fácil, difícil é deixar-se perder nela, encontrando novos caminhos que façam a ruptura com o já conhecido. Benjamin recoloca o duplo sentido de errar, o de equivocar-se, certamente, mas também o de caminhar errante, deixando-se aberto à contingência de novas descobertas. Mais ou menos como Ulisses em sua viagem de regresso à Ítaca, a ilha-pátria, a ilha utópica, a ilha-reconciliação. Perder-se na cidade para poder encontrá-la de uma outra forma exige que os sentidos estejam de certa forma distraídos.

Nesse movimento, o que está em jogo é a possibilidade mesma da experiência, afetar e deixar-se afetar pelo imprevisível e pela expectativa, pela memória e pela esperança. Experiência do adulto que narra suas memórias infantis na cidade que tão bem conheceu, em especial suas partes nobres, no Oeste, Charlottenburg e Grünewald. Experiências fronteiriças, entre a ficção e a realidade, como convém ao exercício da memória. Experiências sensoriais porque a memória involuntária é desencadeada por um gesto contingencial sobre os sentidos, que se no adulto são treinados principalmente para responder, na infância - condição que a criança geralmente habita - eles ainda talvez possam ser formados para a experiência histórica que lhes atravessa e da qual são protagonistas. Experiências sociais porque não propriamente restritas ao universo individual de um menino de cerca de oito anos imerso em cuidados, 
livros, adultos, brinquedos, mas que alcançam a sociedade de um tempo vista em retrospectiva como um problema do presente, como convém a uma boa história materialista da cultura.

Benjamin não foi um errante apenas em sua cidade natal e querida, quando criança, jovem ou adulto, território que deixou definitivamente no início dos anos 1930, quando ficou claro que o fascismo ascendera com força avassaladora. Errou também por Paris, Ibiza, Capri, Marselha, Nápoles, errou por leituras de todos os tipos e por estilos literários na escrita - teses, artigos, ensaios, aforismos, notas, poesia, narrativa -, errou por cafés, errou na imaginação, com uma foto-mapa do Central Park de Nova York - onde nunca chegou a pôr os pés - na parede de uma de suas moradas em Paris. Sua errância tinha, no entanto, os pontos cardeais na cidade de Paris: casas de amigas, cafés, bibliotecas, livrarias, em especial a de Adrienne Monnier ${ }^{1}$, onde encontrava a fotógrafa Gisèle Freund. Monnier é a autora do primeiro tratamento do conceito de aura, fundamental para o ensaio sobre a reprodutibilidade técnica da obra de arte, enquanto são de Freund as mais conhecidas fotos de Benjamin, inclusive as em que aparece trabalhando na Biblioteca Nacional, em Paris.

Benjamin demarca uma importante diferença entre a experiência na própria cidade daquela que se realiza em outra, distante ( fern), mas próxima sensorialmente, porque é nela que se perambula quando de uma visita ou de sua escolha - ou imposição - como novo território a ser habitado. Em suas narrativas radiofônicas destinadas às crianças de Berlim e de Frankfurt, transmitidas no final dos anos 1920 e início da década seguinte, isso se observa com claridade, ao lê-lo falar dos mistérios ou revelações de Berlim - seus mercados, lojas de brinquedos e museus, ruas - em contraste e combinação com os labirintos de Pompeia e Herculano, com as histórias e lendas de bandoleiros etc (BENJAMIN, 1985). O mesmo vale para quando escreve sobre um conterrâneo, como Franz Hessel, ou sobre um estrangeiro que traduziu, como Charles Baudelaire. Na narração sobre a própria cidade, ganha protagonismo a memória e seus labirintos, entre lembrar e esquecer, em ficcionalizar fatos e sensações; no relato sobre outros territórios, vale a mirada sociológica e estética, a sensibilidade traduzida em palavras.

Se Walter Benjamin encontrou no cinema a expressão estética mais elaborada da virada do século dezenove para o seguinte, aquela capaz de corres-

1 Segundo Monnier (2017), a primeira vez em que Benjamin visitou a livraria da Rue de L'Odéon foi em 1930. "Foi durante dez anos um de meus maiores amigos, aquele talvez com que tive o convívio intelectual mais fecundo" (p. 171-172). A amizade com Gisèle Freund, cujo trabalho Benjamin menciona em Pequena história da fotografia, não passou despercebida à livreira (p. 174-175). 
ponder às expectativas políticas revolucionárias do tempo - recolocando, mas em vetor contrário, a pergunta de Martín Heidegger - o cinema o encontrou em alguns momentos. Talvez o mais feliz deles tenha sido aquele realizado por Wim Wenders, não apenas pelas evidentes citações que emergem em seus filmes, mas pelo espírito (Geist) que compartilham. Este espírito é o das imagens, não quaisquer, mas as Denkbilder, as imagens de pensamento, as imagens que pensam (BENJAMIN, 1977a).

A associação entre Wenders e Benjamin é notória e já foi explorada em outros trabalhos (BORDO, 2008; LOUREIRO; RANGEL, 2013; CHAVES, 2016, entre tantos) O próprio cineasta já a reconheceu e a citou (WENDERS, 2015). No septuagésimo-quinto aniversário da morte do filósofo e crítico, o cineasta foi a Portbou, como convidado do Arquivo Benjamin, sediado na Academia das Artes, de Berlim, a celebrar o legado benjaminiano. ${ }^{2}$

Neste texto examino uma das peças cinematográficas mais emblemáticas do período final da Guerra Fria, Asas do desejo, de Wenders, com roteiro dele mesmo, do grande escritor austríaco Peter Handke, com colaboração de Richard Reitinger. Faço isso na expectativa de que seja correto dizer que a arte autêntica exprime grandes questões do tempo. No caso desse filme, de um diretor que tem na insuficiência, no erro e no fracasso temas recorrentes, e considerando que a narrativa histórica e a memória são questões do presente, trata-se, nos termos que propõem Adorno e Benjamin, da história coagulada em imagens expressivas, em jogo de luz (Lichtspiel), como diz uma antiga palavra alemã para cinema.

Dividido em quatro estações, além deste introito e do epílogo, este é um escrito com curvas, ruelas e avenidas, como corresponde a uma cidade, mas também montagens e elipses, como é próprio de um filme, e ainda com palavras às vezes incertas, como é praxe em uma narrativa.

\section{Imagens viajantes}

Em 2015 Nani Moretti apresentou no Festival de Cannes o filme Mia madre (2015). Nele a personagem Margherita (Margherita Buy) é uma diretora de cinema às voltas com o set de filmagem e com a longa enfermidade da mãe. ${ }^{3}$

2 Disponível em: http://www.wim-wenders.com/walter-benjamin-commemoration-in-portbou/. Acesso em: 01 dez. 2015.

3 Não deixa de ser curioso o quanto o cinema é personagem do cinema, assim como escritores têm sido personagens da ficção literária; não deixa de chamar a atenção, igualmente, mas por motivos diversos, a maternidade como assunto (Mãe só tem uma, de Ana Muylaert, Todo sobre mi 
Frente ao primeiro desafio, ela conta com competente e dedicada equipe que a ajuda a lidar com as dificuldades de praxe, incluindo a temperamental e excêntrica estrela estadunidense Barry Huggins, interpretada por John Turturro; para dar solução ao segundo, o irmão, vivido pelo próprio Moretti, deixa o emprego e muda-se para a casa da mãe a fim de cuida-la em seus últimos dias.

Mas há algo que para Margherita parece não encontrar saída, que é a separação de seu marido, ou pelo menos a suspensão do matrimônio, ele que está farto da excessiva dedicação da esposa aos seus próprios projetos, ao filme, ao que diga respeito a si e não necessariamente aos que estão em volta, à relação entre eles. Não é fácil para a diretora, em guerra consigo mesma. Para reaver um pouco do fio condutor das coisas e poder chegar ao sentido que pode atribuir ao presente, ela recorre à rememoração e com ela alcança a segunda metade dos anos 1980. Ao fechar os olhos, está com o então namorado numa longa fila, eles esperam para assistir a Asas do desejo, filme-fetiche daqueles tempos. Ter comparecido juntos ao cinema para assistir a tal película é quase um manifesto estético-afetivo para uma geração.

A obra é singular na longa filmografia de Wenders. Não sendo de Berlim, mas de Düsseldorf, havendo crescido em Oberhausen e estudado artes visuais em Munique, ele deixa a Alemanha tão rápido quanto pode, para seguir filmando na América os seus roadmovies, sendo o mais famoso deles Paris, Texas, com Nastassja Kinski. Nos EUA levará adiante o projeto que sempre se renova da mesma maneira: "Minhas histórias sempre começam com lugares, cidades, paisagens ou ruas. Um mapa para mim é como um roteiro. Quando, por exemplo, nele encontro uma cidade, começo a perguntar, o que lá talvez pudesse acontecer [...]" (WENDERS, 2015, p. 70)

A mudança para terras americanas se dá quatro anos depois da realização de Alice nas Cidades (1974), um trabalho intermediário, fronteiriço entre duas nações, dois mundos, dois tempos, duas gerações. Este filme começa com uma impossibilidade, o malogro na escrita de uma reportagem sobre os Estados Unidos que deveria ter sido elaborada pelo jornalista alemão Philip Winter, personagem que voltará, encarnado pelo mesmo Rüdiger Vogler, vinte anos depois, em outro filme de Wenders, também sobre o fracasso, Lisbon Story (1994). A escrita que não foi feita abre espaço para as imagens, e é com uma

madre, de Pedro Almodóvar, Mama cumple cien años, de Carlos Saura, Contos de Tóquio, de Yasujiro Ozu, A separação, de Asghar Farhadi, um dos Contos de Nova York - o de Woody Allen etc.), algo, aliás, bastante presente na filmografia de Moretti. Se o cinema é uma espécie de arquivo onírico do nosso tempo, há que se observar o que escolhemos - ou o que se nos escolhe - para compô-lo.

4 "Meine Geschichte beginnen stets mir Orten, Städten, Landschaften oder Straßen. Eine Landkarte ist für mich auch gleich ein Drehbuch. Wenn ich z.B. eine Stadt angucke, fange ich an zu fragen, was dort wohl geschehen könnte [...]" 
polaroide que Winter (palavra que significa inverno em alemão, assim como em inglês) mostra para si mesmo o lado B da América. Depois disso, e porque a contingência lhe convida, sai errante pela Alemanha Ocidental, após passar pela Holanda, acompanhando uma menina, Alice, em suas traquinagens nonsense. Não se trata propriamente do País das Maravilhas, mas da nação desgraçada pela guerra e da qual Wenders quer afastar-se. A insólita dupla passa por várias cidades, entre elas, Wuppertal, onde anos depois o cineasta encontrará a bailarina e coreógrafa Pina Bausch, sobre cuja arte fará seu primeiro documentário em três dimensões. $\mathrm{O}$ jornalista e a menina, finalmente, chegam a um lugar, mas que é, paradoxalmente, um meio de transporte. Depois de viajarem em avião, ônibus, carro, balsa, terminam em recomeço, em um trem.

Certa vez, o cineasta disse o seguinte:

Meu nome é Wim Wenders. Nasci na Alemanha logo após o fim da Segunda Guerra Mundial. Cresci num país devastado e bastante triste. Os alemães carregavam nos ombros um grande peso de vergonha e culpa. Assim, desde as minhas mais remotas lembranças, eu sempre quis deixar o meu país para trás. Acabei virando um viajante (WENDERS, 2013, p. 52).

\section{Asas, infância, cidade}

Foi como viajante, e não como turista, que Wenders escolheu Berlim, onde hoje vive, para realizar um filme que é sobre ela, mas, mais que isso, sobre um tempo, uma história e uma utopia. O trabalho só poderia ter sido feito lá, já que o realizador diz ter tentado sempre "[...] ser verdadeiro em relação ao lugar, permitindo que o lugar contasse a sua própria história, a história que não poderia se passar em nenhum outro lugar". (WENDERS, 2013, p. 57).

Para Wenders, há um "sentido de lugar" fundamental para a rodagem de uma película, e ele se divide em dois tipos:

O sentido de lugar pode ter duas expressões muito diferentes. Para os que ficam em casa ele pode ser uma noção de pertencimento. Existem os cineastas que só exploram os seus próprios territórios, como Fellini, Ozu e muitos outros. E existem os que viajam e que exploram os territórios estrangeiros onde o sentido de lugar é antes uma noção de descoberta. Eu sou antes um cineasta dessa segunda categoria, junto com muitos outros (2013, p. 57). 
O tema dos anjos foi encontrado, conta, ao caminhar pela cidade, depois de ter considerado a possibilidade de muitas outras abordagens. Ele diz ter visto anjos por toda parte, em monumentos, fontes, estátuas (WENDERS, 2015). Benjamin (2012) também vira anjos pela Berlim da sua infância, na árvore de natal, nas fontes do Tiergarten, enorme parque na região central da cidade, minúsculas estátuas compondo secundariamente as maiores, miudezas que só uma criança, com sua pouca altura e muita liberdade, pode ver. Encontrou outros anjos na sua vida, o último deles aparece em suas teses sobre filosofia da história, o Anjo de Paul Klee (BENJAMIN, 2016).

Quando Asas do desejo é realizado e apresentado, ainda estamos sob a separação da cidade de Berlim, da Alemanha, do mundo, em dois blocos que configuram a Guerra Fria, um representando a OTAN (Organização do Tratado do Atlântico Norte), com liderança dos Estados Unidos da América, outro o Pacto de Varsóvia, liderado pela então União das Repúblicas Socialistas Soviéticas. A cidade foi um dos principais palcos dessa guerra cheia de batalhas, tendo sido a construção do muro o seu marco mais expressivo. Foram, igualmente, palco dessa conflagração permanente a corrida armamentista, os combates pela descolonização, o esporte, a contenda espacial. Em 1962, pouco antes de que fosse erguida a barreira a separar os dois lados da antiga - e hoje novamente - capital da Alemanha, tanques de lado a lado manobraram em ameaça correspondente à Crise dos Misseis - o armamento soviético instalado em Cuba e voltado para os EUA -, quando se supõe que o mundo esteve à beira de uma guerra nuclear. Ninguém poderia prever que pouco mais de dois anos depois da première do filme a história daria uma dessas reviravoltas que nos deixam atônitos, e o Muro cairia. Com ele, toda uma maneira de ver o mundo. Mas isso talvez não deixe Asas do desejo anacrônico. Ou, por outra, talvez o filme de trinta e poucos anos atrás seja anacrônico e por isso mesmo tenha valor. Walter Benjamin (1977b) escreveu que o moderno se opõe ao antigo, mas que o novo não se opõe ao que é velho, mas ao sempre-igual. Asas do desejo, e não porque acaba de ser restaurado em nova tecnologia, a $4 \mathrm{k}$, segue sendo novo ou, nos termos do próprio Benjamin e de Adorno, atual.

O filme conta a história de dois anjos que deambulam pela cidade de Berlim, frequentemente sobre ela, mas apenas em sua porção ocidental. O título em alemão é Der Himmel über Berlin (O céu sobre Berlim), mas é sobre uma metade dela que tudo se desenrola. Wenders tentara com a administração comunista da República Democrática Alemã, em cujos cinemas seus filmes eram exibidos, a autorização para filmar do outro lado do Muro, mas ela não foi concedida. Na filmografia do Leste, com muitas obras de ótima qualidade, diga-se de passagem, era proibido mostrar ou mencionar a existência do Muro. Eventualmente, esses seres alados ultrapassam o Muro, imateriais que são, mas 
não vão além da zona de segurança do sistema de fronteiras entre o que foram, até 1990, duas cidades, dois países. Há no filme outros personagens, entre eles, e são muito importantes, crianças, um velho e uma trapezista.

Damiel (Bruno Ganz) e Kassiel (Otto Sander) são dois anjos que não têm lá muito poder, é preciso reconhecer. Apaziguam a angústia de alguns, o que não é pouco, com outros apenas se solidarizam, sem muito poder fazer. Escutam os pensamentos, em especial os dos momentos-limite que todos temos, quando a imaginação vai longe e frequentemente nos intoxica. No geral, são impotentes. Anjos caídos, como os definiu o próprio diretor (WENDERS, 2015) em um ensaio, não podem evitar a queda e a morte de um jovem em Wedding, bairro do Nordeste de Berlim, parte de um lado do Muro, parte do outro. O suicídio, a última desrazão dos angustiados, é tema não raro da filmografia de Wenders, assim como são o fracasso, o medo, a via ordinária, os marginais, o esquecimento, a culpa. Temas que também comparecem na obra de Benjamin, que não apenas escreveu sobre o suicídio, mas planejou realiza-lo no início dos anos 1930, algo que termina por acontecer em 1940.

Damiel e Kassel veem-se um ao outro, assim como reconhecem outros anjos, mas fora os outros seres da mesma espécie, apenas as crianças podem saber deles. Disso somos avisados no início do filme, quando um avião está para pousar no Aeroporto Tegel. Era de avião que preferencialmente se chegava a Berlim Ocidental, meia-cidade encravada no coração da Alemanha do Leste. Dentro da máquina voadora, Kassiel anda pelo corredor e se aproxima da poltrona em que está uma menina que o vê e lhe sorri, mas logo volta ao desenho ao qual se dedicava. Igualmente a bordo está o ator Peter Falk que, fazendo o papel de si mesmo, lembra, mirando pela janela, de marcadores históricos da cidade de Berlim, como a visita de Kennedy e a construção do muro. Saberemos que está por chegar à cidade para um filme sobre o nacional-socialismo, que fora igualmente um anjo, antes de ser o detetive Columbo da série estadunidense e de ser ator em um filme dentro do filme.

Mas há também crianças que são visitadas pelos anjos em suas casas, com seus brinquedos montados, suas deficiências, sua compulsão à mordaça tecnológica que é a televisão. Outras delas atravessam a rua e, no Tiergarten, olham para a torre encimada pela Deusa Vitória, alada, em voo. Ao lado dela Damiel, fazendo-lhe par, é reconhecido pelos pequenos. Não são poucas as sequências em que crianças dão contorno à narrativa, mesmo depois que o anjo cai. Wenders segue aqui uma longa tradição romântica, partilhada também por Benjamin, que diz que a infância conserva algo da experiência que a vida adulta faz perder. Retoma, portanto, um dos motivos centrais de Alice nas cidades, quando as incertezas da menina são antes liberdade que dificuldade. Talvez porque na infância os sentidos estejam mais distraídos e, portanto, mais aptos a errar. Só 
assim, talvez, é que pode ver um anjo. A distração, como lemos no ensaio sobre a reprodutibilidade técnica da obra de arte (BENJAMIN, 1977c), pode sim, ser produtiva, na medida em que abre os sentidos, deixando-os desintoxicados da predisposição compulsória. Se para Benjamin o olhar é o sentido-chave na modernidade, ele se combina, com muita força, na experiência infantil, com o tato (VAZ, 2012). Mas também com outros, como aquele que faz apaziguar o espírito em momento de sofrimento que antecede a escola, quando aroma, imagem, pensamento, voz e textura do objeto se encontram na experiência como que completa dos sentidos:

Nasceu em mim [o desejo pedido à fada] com o candeeiro que nas manhãs de inverno, às seis e meia, se aproximava da minha cama e projetava no teto a sombra da criada. Ela acendia o fogão. Em breve a chama, que parecia estar encurralada numa gaveta demasiado pequena onde quase não se podia mexer de tanto carvão, olhava para mim. [...] Quando o lume já estava aceso, ela punha uma maçã a assar no forno. Daí a pouco as grades da portinhola desenhavam-se no soalho, num flamejar vermelho. E o meu cansaço imaginava que essa imagem já lhe bastava para o dia inteiro. Era sempre assim a essa hora; só a voz da criada perturbava o recolhimento com que a manhã de inverno costumava casar-me com as coisas do meu quarto. Ainda as persianas não estavam abertas, e já eu destrancava pela primeira vez a portinhola do fogão para ver como estava a maçã. Por vezes, ainda mal se alterara o seu aroma. E eu esperava pacientemente até me parecer sentir o cheiro espumoso que vinha de uma célula da manhã de inverno, mais profunda e mais discreta que o cheiro da árvore na noite de Natal. Lá estava o fruto escuro e quente, a maçã que chegava até mim, familiar e apesar disso mudada, como um velho conhecido depois de uma viagem. Era a viagem através da terra escura do calor do fogão, em que tinha absorvido os aromas de todas as coisas que o dia me reservava. Por isso, sempre que aquecia as mãos nas suas faces lisas, não estranhava a vontade hesitante que sentia de mordê-la. Pressentia que a fugaz mensagem que ela me trazia com o seu aroma me poderia escapar facilmente ao passar pela minha língua. Era a mensagem que por vezes se apoderava tão fortemente do meu coração que me consolava ainda no caminho apressado para a escola. Mas uma vez chegado, o simples toque da carteira fazia regressar, dez vezes maior, todo o cansaço que antes parecia ter-se dissipado. E com ele aquele desejo: poder dormir à vontade (BENJAMIN, 2012, p. 82-83). 


\section{O anjo, a memória, a trapezista}

Damiel e Kassiel sabem tudo o que acontece e aconteceu em Berlim, desde que não havia cidade, mas apenas estepes e gelo, quando já vagavam por esse lugar ao qual, diz Wenders (2015), tiveram sua eterna existência condenada. O pior de todos, o lugar da Guerra, o território, no entanto, para onde o diretor resolveu deslocar-se quando ao decidir-se pela volta à Alemanha. É como se dissesse: se é para estar lá, então que seja no âmago da destruição, onde tudo fracassou e a história é um monte de escombros que os anjos observam, impotentes. Por isso Damiel e Kassiel veem também imagens de arquivo de sua intemporalidade, quando surge a Berlim inteiramente destruída, com suas crianças nas ruas, as mulheres em longas filas à espera de comida, ou lado a lado em incessante trabalho colaborativo. São anjos confinados no território etéreo da cidade em ruínas não falam para Deus, muito menos Deus fala com eles. Como o anjo de Paul Klee, os de Wenders são seres com poucos recursos:

Há um quadro de Klee intitulado Angelus Novus. Representa um anjo que parece preparar-se para se afastar de qualquer coisa que olha fixamente. Tem os olhos estão esbugalhados, a boca escancarada e as asas abertas. $\mathrm{O}$ anjo da história deve ter esse aspecto. Voltou o rosto para o passado. A cadeia de fatos que aparece diante dos nossos olhos é para ele uma catástrofe sem fim, que incessantemente acumula ruínas sobre ruínas e lhas lança aos pés. Ele gostaria de parar para acordar os mortos e reconstruir, a partir dos seus fragmentos, aquilo que foi destruído. Mas do paraíso sopra um vendaval que se enrodilha nas suas asas, e que é tão forte que o anjo já não as consegue fechar. Esse vendaval arrasta-o imparavelmente para o futuro, a que ele volta as costas, enquanto o monte de ruínas à sua frente cresce até o céu. Aquilo a que chamamos o progresso é este vendaval (BENJAMIN, 2016, p. 14).

Condenados ao comedimento da imaterialidade, Damiel e Kassiel vão para lá e para cá, no espaço restrito e no tempo infinito, ambos suspensos pela falta de experiência sensível, histórica, que os detém. Vagam, conversam entre si, lembram-se de tempos imemoriais, são contemplativos. Os anjos se recordam de tudo e isso só é possível porque não têm corpo, portanto, não há dores, não há traumas que pudessem disparar o trabalho de esquecimento. Suas memórias (ou o que seriam memórias se fossem eles corpos) não são fragmentadas ou 
incertas. Não se fatigam, não sabem como é a cor ou o perfume das coisas. Não sofrem, tampouco são infelizes, mais ou menos como os marinheiros de Ulisses que chegam à Ilha dos Lotófagos e experimentam o lótus, a planta entorpecente, ficando entregues aos próprios instintos, segundo a interpretação que Horkheimer e Adorno (1997) fazem da Odisseia, de Homero. Os anjos não desejam, propriamente, embora pelo menos um deles, quisesse desejar. Estão, no entanto, limitados pela própria interdição.

Um deles como que se aborrece com todo esse tédio imaterial e começa a colocar em dúvida o valor da imortalidade. O golpe definitivo é o encontro com uma trapezista. É linda a abertura da sequência que mostra ao anjo, e a nós, a beleza singular de Marion, interpretada por Solveig Dommartin. Duas crianças com um imã pescam uma moeda em um bueiro, observadas pelo anjo. A câmera se movimenta do primeiro plano nos garotos para um plano aberto em outro menino, encostado em uma parede. Ele está triste e isolado, o que nos faz ver que a infância não é apenas júbilo e alegria. A tristeza da criança, a câmera, o prolongamento do olho humano, como a chamou Benjamin (1977c), nos leva a um portão que dá para um pátio interno, possivelmente, construção comum em várias cidades europeias, em Berlim, em particular. Mas, não, o que vemos, em superplano é um espaço baldio e amplo, e nele, o circo, essa comarca imaginária em que sobrevive uma forma anacrônica de divertimento.

O circo é mal-ajambrado, nele todos fazem quase tudo porque a estrutura é precária e simples. Ele já tem que baixar a lona e os trailers irão para o estacionamento de inverno, não há mais dinheiro, o público é escasso. Antes, no entanto, ainda há tempo para um último espetáculo, ou dois: o primeiro numa tarde, para crianças, com palhaços e números em que predominam as fantasias de animais, remetendo, tudo, à encenação medieval: de fato, adultos e crianças parecem se confraternizar em prazer comum, como em um tempo em que a separação geracional ainda não encontrava com clareza os limites de sua realização, quando jogar era coisa de todos. Cassiel comparece à matinê e as crianças, divertindo-se, acusam sua presença que, no entanto, é quase indiferente para elas. Depois, o último espetáculo, à noite, em que Cassiel também comparece, quando o trapézio faz Marion ser soberana, a "voar como um anjo", como the orientara seu preparador em um ensaio. Ela tem asas coladas às costas.

Em meio a tantas incertezas, Marion não sabe muito bem o que fazer, flerta com o erro e o suicídio no trapézio, mostra-se a si mesma nua dentro do trailer que lhe é morada, envolta no conjunto de objetos que materializam sua memória, entre eles um disco de Nick Cave, umas fitinhas do Senhor do Bonfim. Presentes de amores antigos, talvez, que podem ser lembrados porque Marion é incerteza e melancolia, mas também desejo. Um novo amor se avizinha no anjo que a observa em preto e branco, como durante quase toda a primeira parte da 
película, mas, em momento de dúvida, de quase não mais ceder do desejo, em cores. A imaterialidade angelical é em tons de cinza.

Damiel resolve, então, levar às últimas consequências sua condição de anjo caído. Despenca do mundo da pura imagem de si mesmo para a dureza do chão de Kreuzberg, bairro na porção Leste em Berlim Ocidental - povoado por punks, imigrantes, principalmente turcos, estudantes e prédios ocupados - em que começa sua nova aventura, desta vez condenada a um dia terminar. Caído perto do Muro, agora vê e é visto. Em cores.

O agora humano sente frio, pergunta sobre as cores, quer tomar um café, vaga pela cidade sentindo o peso da existência. $O$ anjo quer sofrer, prova de seu próprio sangue ao levemente ferir-se e se surpreende com o gosto, encontrando algo de natureza - esse negativo da história, mas que a compõe - em si mesmo.

Coloca-se para ele a possibilidade concreta da experiência, o jogo de afetar e deixar-se afetar pelo outro, pelo objeto, pelo desejo.

Damiel caminha, dorme ao relento, encontra Peter Falk, busca o terreno em que já não está o circo, erra por Berlim até chegar a um clube noturno em que Nick Cave faz as honras da casa. Lá encontra Marion e cede ao amor, aquela experiência que, como explicam Horkheimer e Adorno (1997), é sempre de perda.

\section{Contador de Histórias}

Em uma sequência logo em seu início, o filme mostra, em câmera subjetiva, a Biblioteca Municipal de Berlim. Vemos uma estante de livros à nossa frente, quando pensamentos diversos se misturam e se tornam vozes para os anjos. $\mathrm{O}$ de uma moça deles fala de Walter Benjamin e sua relação com o quadro de Paul Klee, o Anjo da História.

Walter Benjamin comprou em 1921 a aquarela de Paul Klee, Angelus Novus. Até o momento de sua fuga de Paris, ele o manteve na parede de suas diferentes salas de trabalho. Em seu último escrito, Sobre o conceito de história (1940), ele interpretou a imagem como alegoria de um olhar que se volta para a história! ${ }^{5}$ (WENDERS, HANDKE, 1990, p. 23).

5 “Walter Benjamin kaufte 1921 Paul Klees Aquarell Angelus Novus (Abb 34). Bis zu seiner Flucht aus Paris im Juni 1940 hing es in seinen wechselnden Arbeitszimmern. In seiner letzten Schrift, Über den Begriff der Geschichte (1940), interpretierte er das Bild als Allegorie des Rückblicks auf die Geschichte!” (WENDERS, HANDKE, 1990, p. 23. 
Um anjo entra e segue pelas escadas. Vê pares seus, sentados em lugares improváveis ou em pé, inclinados sobre leitores e estudantes, zelando por eles que parecem estar, alguns, angustiados. Como de início não há crianças na Biblioteca, só os anjos veem os outros de sua espécie. Cuidam das pessoas, anjos-da-guarda, são cuidados por livros, objetos em que se impregna a imaginação. $\mathrm{O}$ anjo que nos guia acompanha um velho cujo nome nada tem de casual.

Para aumentar o anacronismo de tudo e de todos há, então, um Homero na narrativa, ele mesmo um contador de histórias que, silencioso, mantém-se como guardião da memória. Como convém à legitimação da narrativa, trata-se de um velho que ainda recorda o entreguerras, período de abundância e movimento cultural como nunca antes em Berlim, esfumaçado quando da chegada do nacional-socialismo ao poder, definitivamente, em 1933.

Sem ouvintes, isolado, ele já não pode exercer a arte de narrar, aquela que:

[...] prospera por muito tempo no âmbito do trabalho das mãos - nos campos, nos mares e depois nas cidades -, é ela mesma uma espécie de forma artesanal da comunicação. O importante para ela não é transmitir o puro "em si" da matéria, como se tratasse de uma informação ou de um relatório. Faz descer a matéria à vida de quem conta, para fazer emergir de novo, a partir dele. Desde modo, a marca própria de quem conta é detectável na história narrada, tal como a marca do oleiro no vaso de barro (BENJAMIN, 2015, p. 157-158).

O velho que procura livros e neles imagens antigas na Biblioteca, observado por crianças, agora presentes, erra pelos labirintos da memória frente a imagens de um livro, para logo procurar errar pela Potsdamer Platz, na parte central da antiga Berlim. Mas isso logo não é possível, porque acontece que a grande região burguesa de sua infância e juventude é agora um monte de escombros, as antigas casas comerciais, ruas e cafés já não existem, e em seu lugar vemos uma extensa porção de terra arrasada. Exausto, depois de vagar a esmo e não conseguir deixar-se levar pelos pontos cardeais que a praça uma vez ofereceu, e sempre escoltado pelo anjo Kassiel, deixa-se cair em um avelhantado sofá, desiludido. Ele vaga fora do tempo porque não o pode encontrar. O espaço, no entanto, é puro vazio. Não há como deixar de notar que a mesma região será, poucos anos mais tarde, o maior canteiro de obras da Europa, sendo hoje a parte "mais moderna" da cidade. É onde também, ao se tentar exercer a lembrança, na forma de culto ao monumento turístico, os restos do Muro, há 
mais esquecimento, apagamento da memória, reafirmação de uma narrativa histórica calcinada, a dos vencedores.

\title{
Desejo e Formação
}

Rodado em grande parte em preto e branco (quando da mirada dos anjos), Asas do desejo fala de uma Berlim e de um mundo que já não existem, de uma forma artística de entretenimento em decadência - o circo - de um improvável amor entre um anjo encarnado e uma trapezista, põe em primeiro plano crianças brincando e um velho que não tem para quem narrar suas recordações. Nesse anacronismo está sua força.

Em primeiro lugar porque se trata de pensar a cidade e o cinema (um de seus artefatos centrais) como educadores dos sentidos, impulsos que propõem uma formação sensível que coloca o desejo como protagonista. Daí a importância da abertura para a contingência, condição do exercício da liberdade, da errância do pensamento, do corpo pela cidade, das sensibilidades no jogo de afetar e deixar-se afetar. Como elege, livremente, o anjo Cassiel. Errância como livre transcurso da experiência, afinal,

\begin{abstract}
Não há nada de especial em não nos orientarmos numa cidade. Mas perdermo-nos numa cidade, como nos perdemos numa floresta, é coisa que precisa de se aprender. Os nomes das ruas têm então de falar àquele que por elas deambula como o estalar de ramos secos, e as pequenas vielas no interior da cidade mostrar-lhe a hora do dia com tanta clareza quanto um vale na montanha. Aprendi tarde essa arte; ela preencheu o sonho cujos primeiros vestígios foram os labirintos nos mata-borrões dos meus cadernos. (BENJAMIN, 2012, p. 78).
\end{abstract}

Para tanto é preciso, então, fazer o elogio do errar também como equívoco, momento que pode ser igualmente produtivo para a formação, se um dos quesitos básicos para a experiência estiver colocado, qual seja, o tempo como qualidade e não como quantidade. Benjamin escreve que o processo de escuta e incorporação das experiências narradas 
[...] exige uma disposição livre de tensões, algo que se torna cada vez mais raro. Se o sono é o ponto culminante do relaxamento do corpo, a disponibilidade (Langweile) corresponde a esse ponto no plano mental. A disponibilidade é o pássaro onírico que choca o ovo da experiência. $\mathrm{O}$ sussurrar da folhagem na floresta espanta-o (BENJAMIN, 2015, p. 157).

Coloca-se a necessidade de um novo regime de tempo, ampliado, sem limites previamente postos. Nele as imagens talvez pudessem pensar, ser experiências da imaginação, esta sim, potência do desejo que promove uma dialética em suspensão (Dialektik im Stillstand). Para tanto, afastar-se da etérea vida angelical e aceitar imiscuir-se na história é admitir um tempo que pode ser detido, tempo pleno de Agora (Jetztzeit) (BENJAMIN, 2016, 18), em que a história é reconhecida em sua coagulação.

Asas do desejo é um filme que diz sobre o tempo e sua apreensão, sobre o desejo e a formação subjetiva, esta que só se dá na consciência da encarnação e de suas vicissitudes. É também sobre a tríade imagem, magia, imaginação. Diz Wenders (1990) que “[...] Todos os filmes começam com memórias, todos os filmes são também uma soma de muitas memórias. Por outro lado, muitas memórias nascem através dos filmes. $\mathrm{O}$ cinema criou também, ele próprio, muitas memórias". (p. 57). Como acervo onírico do século vinte - e ainda do nosso -o cinema mostra que a imagem em movimento é corpo e por isso os seres angelicais não podem ter desejos, a não ser o impulso, a curiosidade, talvez a esperança de desejar, seja lá o que for.

Um pouco como Alice, nas cidades. Um pouco como no poema de Peter Handke que abre o filme, sua Lied vom Kindsein:

\author{
Als das Kind Kind war, \\ ging es mit hängenden Armen, \\ wollte der Bach sei ein Fluß, \\ der Fluß sei ein Strom, \\ und diese Pfütze das Meer.
}

Muito como na coragem de Damiel, de renunciar à imortalidade e tornar Berlim não mais o campo do puro sonho, mas sua materialização em desejo, em história, em tempo.

É o desejo que nos permite a inscrição na história. 


\section{REFERÊNCIAS}

ADORNO, T. W. Nachwort zur “Berliner Kindheit um Neunzehnhundert”. Gesammelte Schriften 20. Frankfurt am Main: Suhrkamp, 1997a.

BENJAMIN, W. Denkbilder. In: Iluminationen: Ausgewählte Schriften. Frankfurt am Main, Suhrkamp, 1977a.

BENJAMIN, W. Zentralpark. Gesammelte Schriften (I-2). Frankfurt am Main: Surhkamp, $1977 b$.

BENJAMIN, W. Das Kunstwerk im Zeitalter seiner technischen Reproduzierbarkeit (Erste Fassung). Gesammelte Schriften (I-2). Frankfurt am Main: Surhkamp, 1977c.

BENJAMIN, W. Aufklärung für Kinder. Frankfurt am Main: Surhkamp, 1985.

BENJAMIN, W. Infância berlinense: 1900. In: BENJAMIN, W. Rua de mão única. Infância berlinense: 1900. Belo Horizonte: Autêntica, 2013, p. 67-116. (Organização e tradução de João Barrento).

BENJAMIN, W. O contador de histórias. In: BENJAMIN, W. Linguagem, tradução, literatura (filosofia, teoria crítica). Lisboa: Assírio \& Alvim, 2015. p. 147-178. (Organização e Tradução de João Barrento).

BENJAMIN, W. Sobre o conceito da história. In: BENJAMIN, W. O anjo da história. Belo Horizonte: Autêntica, 2016. p. 7-20. (Organização e Tradução de João Barrento).

BORDO, J. (2008). The Homer of Potsdamerplatz-Walter Benjamin in Wim Wenders's Sky Over Berlin/Wings of Desire, a Critical Topography. Images. n. 2, 2008. p. 86-109.

CHAVES, E. Memória, história e narração: O céu sobre Berlim ou Wim Wenders, leitor de Benjamin. Viso: Cadernos de estética aplicada. Belo Horizonte, v. X, n. 18, jan/jun 2016. p. 111-123.

HORKHEIMER, M.; ADORNO, T. Dialektik der Aufklärung: Philosophische Fragmente. Gesammelte Schriften 3. Frankfurt am Main: Suhrkamp, 1997.

LOUREIRO, R.; RANGEL, S. R. Evidências da memória: Diálogos entre Walter Benjamin e Wim Wenders. Pró-Discente: Caderno de Prod. Acad.-Cient. Prog. Pós-Grad. Educ., Vitória-ES, v. 19, n. 1, jan./jun. 2013.

MONNIER, A. Rua do Odéon. Belo Horizonte: Autêntica, 2017. (Tradução de Júlio Castañon Guimarães).

WENDERS, W. Cinema além das fronteiras. In: MACHADO, Cassiano Elek. Pensar a cultura. Porto Alegre: Arquipélago, 2013. p. 54-68. (Tradução de Rodrigo Breunig).

WENDERS, W. Unmögliche Geschichten. Vortrag auf einem Kolloquium über Erzähltechniken. In: Die Logik der Bilder. Essays und Gespräche. 3. ed. p. 68-77. Frankfurt am Main: Verlag der Autoren, 2015. (Traduzido do orginal em francês por Marianne Karbe). 
VAZ, A. F. Elogio do anacronismo: afetos, memórias, experiências, em Asas do...

VAZ, A. F. Educação, experiência, sentidos do corpo e da infância (um estudo experimental em escritos de Walter Benjamin). In: PAGNI, P. A.; GELAMO, R. P. (Org.). Experiência, educação e contemporaneidade. Marília; São Paulo: Poiésis, Oficina Universitária; Cultura Acadêmica, 2012. p. 35-50.

WENDERS, W.; HANDKE, P. Der Himmel über Berlin. Ein Filmbuch. Frankfurt am Main: Suhrkamp, 1990.

Texto recebido em 12 de novembro de 2018.

Texto aprovado em 14 de dezembro de 2018. 